Behavior and Social Issues, 27, 31-46 (2018). C Pedro Felipe dos Reis Soares, Ana Paula Martins Cavalcante Rocha, Thais Maria Monteiro Guimarães, Felipe Lustosa Leite, Maria Amália Pie Abib Andery, \& Emmanuel Zagury Tourinho. Readers of this article may copy it without the copyright owner's permission, if the author and publisher are acknowledged in the copy and the copy is used for educational, not-for-profit purposes. doi: 10.5210/BSI.V.27I0.8252

\title{
EFFects of Verbal AND Non-Verbal Cultural CONSEQuences ON CULTURANTS
}

\author{
Pedro Felipe dos Reis Soares ${ }^{1}$ \\ Ana Paula Martins Cavalcante Rocha \\ Thais Maria Monteiro Guimarães \\ Universidade Federal do Pará \\ Felipe Lustosa Leite \\ Imagine Behavioral Technology \\ Universidade Federal do Pará \\ Maria Amália Pie Abib Andery \\ Pontifícia Universidade Católica de São Paulo \\ Emmanuel Zagury Tourinho \\ Universidade Federal do Pará
}

\begin{abstract}
Experiments about the effects of cultural consequences (CCs) upon culturants (IBCs+APs) suggest an important role of two specific variables: competition between operant contingencies and metacontingencies, and the antecedent and consequent verbal events to the participants' behavior. The present study manipulated the presentation of verbal (VCCs) and non-verbal (NVCCs) cultural consequences, examining their effects on culturants under conditions of competition and no competition between operant contingencies and metacontingencies. One hundred and twenty-three college students composed four microcultures. We programmed two microcultures with an ABABCD design and two microcultures with a BABACD format. Competition and noncompetition between operant contingencies and metacontingencies were also manipulated. In Condition A verbal and nonverbal cultural consequences were contingent on target culturants; in Condition B there were only nonverbal cultural consequences; in Condition $\mathrm{C}$ only verbal cultural consequences were presented; and in Condition $\mathrm{D}$ there was no cultural consequence programmed. Microcultures with no competition exhibited more stable rates of target-
\end{abstract}

\footnotetext{
${ }^{1}$ This work was partially supported by the National Council for Scientific and Technological Development (Conselho Nacional de Desenvolvimento Científico e Tecnológico - CNPq) and is based on the scientific initiation reports produced by the first two authors. We thank PROPESP/UFPA for the payment of translation fees. We also thank Bruno Rodrigues, Denilson Paixão, Gehazi Bispo, Jade Martins, Luiz Felipe Alves, and Yan Valderlon for their assistance during data collection. E-mail: eztourinho@gmail.com
} 
culturants. Verbal and non-verbal cultural consequences, operating in conjunction, selected and maintained target-culturants whether or not competition was operating. Verbal cultural consequences in isolation also had a selective effect, provided that they were not associated with non-verbal cultural consequences in the previous condition. Non-verbal cultural consequences in isolation selected target culturants only in the absence of competition, but maintained them whether or not competition was operating. In the absence of cultural consequences, the rate of target culturants decreased. Verbal variables defined as verbal cultural consequences showed differential effects that need consideration and additional investigations.

KEYWORDS: competition between operant contingencies and metacontingencies, metacontingencies, verbal cultural consequences.

Recent experimental studies (e.g., Azevedo \& Todorov, 2016; Baia, Lemes, Biano, Pereira, \& Sousa, 2017; Baia \& Vasconcelos, 2015; Borba, Tourinho, \& Glenn, 2017; Carvalho, Couto, Gois, Sandaker, \& Todorov, 2017; Gomes \& Tourinho, 2016; Hosoya \& Tourinho, 2016; Marques \& Tourinho, 2015; Vasconcelos \& Todorov, 2015) have shown the selection of interlocking behavioral contingencies (IBCs) and their aggregate products (APs) by cultural consequences (CCs), providing empirical support for the concept of the metacontingency (Glenn, 2004; Glenn et al., 2016).

Some studies on the selection of culturants (i.e., IBCs + APs) by CCs involve competition conditions between operant contingencies and metacontingencies (i.e., conditions in which the production of CCs requires individual responses that generate operant consequences with smaller magnitude than alternative individual responses). The effects of this type of competition have been examined through various experimental protocols: the Prisoner's Dilemma game adapted to metacontingency arrangements (Costa, Nogueira, \& Vasconcelos, 2012; Ortu, Becker, Woelz, \& Glenn, 2012), the task of choosing rows in a colored matrix (Borba et al., 2017; Gomes \& Tourinho, 2016; Hosoya \& Tourinho, 2016), and the task of entering numbers on a screen managed by software (Magalhães, 2013). The variety of arrangements and similarity of results confer generality to the reported data, allowing access to other levels of complexity of cultural phenomena through the concepts and methods involved in the experimental study of metacontingencies (Tourinho \& Vichi, 2012).

Accordingly, these experimental settings are analogous to some conditions outside the laboratory, in which the coordination of behaviors is necessary to produce a relevant result to the group. For example, the Government of Brazil, through the social program "Programa Bolsa Familia", tries to improve the health conditions and the level of education of poor and extremely poor families by giving them a cash benefit if they meet some conditions required by the program. One such condition is that children and adolescents of these families attend $85 \%$ of their classes at school each month. To reach this level of attendance, family members must coordinate their behaviors to deal with competing contingencies, such as the early inclusion of youth in the labor market. The maintenance of children and adolescents' school attendance may enable favorable and delayed consequences for themselves and their families (for a complete analysis, see Fava \& Vasconcelos, 2017). Thus, that kind of coordination and its results are in competition with contingencies in which individual responses can produce operant consequences that are more favorable to the individual (e.g., of greater magnitude, reinforcing, or non-aversive).

Another important issue identified in studies with experimental arrangements of cultural selection studies is the verbal interaction among participants. The selection of culturants is more consistent when there is a possibility of verbal interaction between group members (e.g., Costa et al., 2012; Sampaio et al., 2013). Under these circumstances verbal events may have antecedent or 


\section{EFFECTS OF VERBAL AND NONVERBAL CULTURAL CONSEQUENCES}

consequent functions. The rules drawn up by members of microcultures ${ }^{2}$ specifying how participants must answer are an example of verbal antecedents (Smith, Houmanfar, \& Louis, 2011). Some studies have noted that such descriptions are a requisite ${ }^{3}$ for cultural selection and can be interpreted as a correlated product of cultural contingencies (Baia \& Vasconcelos, 2015; Gonçalo, 2015). An example of verbal events with consequent functions are verbalizations of approval or disapproval of the behavior of a microculture member, observed in experimental sessions (Tourinho, 2013). Disapproval has been referred to as an ethical sanction (Gomes \& Tourinho, 2016; Hosoya \& Tourinho, 2016), alluding to the ethical control of behavior by group members (Skinner, 1953).

When approvals and/or disapprovals are contingent on the behavior of a microculture member, they can be treated as operant consequences that are additional to programmed consequences, and may also be considered as support consequences (Andery, Micheletto, \& Sério, 2005; Tadaiesky \& Tourinho, 2012). Similarly, approvals and disapprovals may be contingent on culturants, a circumstance that would be more appropriately designated as verbal cultural consequences (VCCs), additional to programmed non-verbal cultural consequences (CCs or NVCCs). The term "verbal" relates only to the very nature of events; it is not a new category of verbal behavior. Verbal stimuli such as "Congratulations, you did well this time!" contingent on a culturant, would be an example of a VCC, whereas the donation of a school item, also contingent on a given culturant, would be an example of an NVCC. Azevedo and Todorov (2016) and Vasconcelos and Todorov (2015) manipulated VCCs in a task involving moving pieces on a chessboard. The results indicated that these consequences selected culturants, although there were no explicit distinctions between operant contingencies and metacontingencies.

There is little information about the effects of verbal consequences (both operant and cultural) on metacontingency arrangements. Frequently, members of microcultures emit consequences of this kind, without any proper experimental control. In addition, evidence of the selective effect of CCs under conditions of competition with operant contingencies as well as of the selective effects of verbal consequences suggest the need for an experimental assessment of these verbal and nonverbal consequences on the selection of operant contingencies and metacontingencies. This study evaluated the effects of VCCs and NVCCs under specific conditions. First, the experimental arrangement allows for the measurement of operant behavior and behavior coordination selection on a specific task - choosing rows in a matrix (Borba et al., 2017; Gomes \& Tourinho, 2016; Hosoya \& Tourinho, 2016). Second, VCCs (approval and disapproval) were directly manipulated and could be added to NVCCs (items for donation to a community school) allowing for measurement of their specific effects. Finally, the experimental design allows the evaluation of the effects of competition between operant contingencies and metacontingencies.

Previous studies (e.g., Gomes \& Tourinho, 2016) have already suggested that verbal interaction may be even more relevant in cultural selection when there is competition between metacontingencies and operant contingencies. To date, there is no experimental evaluation of this possibility. Therefore, the aim of this study was to evaluate the effects of VCCs of approval and disapproval and of NVCCs on culturants under conditions of competition and non-competition

\footnotetext{
${ }^{2}$ Laboratory microculture is an expression originally used in studies of social psychology (e.g., Gerard et al, 1956; Jacobs \& Campbell, 1961; Weick et al, 1971). It refers to small groups of people usually with three members, who participate in the same experimental manipulation.

${ }^{3}$ Conversely, some recent studies have been exploring the possibility of investigating metacontingencies with nonhumans (e.g., Carvalho, 2016; Velasco, Benvenuti, Sampaio, \& Tomanari, 2017).
} 
SOARES ET AL.

between metacontingencies and operant contingencies. We also evaluated the effects of the order of exposure to VCCs and NVCCs.

\section{Participants}

\section{Method}

A total of 123 college students from various courses, except psychology, participated in the study. Participation was conditional on the reading and signing of an informed consent form. The participants composed four experimental microcultures: M1 (32 participants), M2 (29 participants), M3 (33 participants), and M4 (29 participants). Each microculture featured three cultural-behavioral lineages (Glenn, 2003), in which participants were sequentially replaced (see the "Participant replacement" section below). Table 1 shows the distribution of participants, their cultural-behavioral lineages, and corresponding microcultures.

\section{Materials and Equipment}

Experimenters used a laptop computer equipped with Microsoft Excel 2013® to record the choices of the participants; a digital camcorder with tripod for audiovisual recording; pens, instruction sheets, and paper for recording; and plastic containers for storage of tokens.

Individual consequences (ICs) consisted of tokens that were exchangeable for money. NVCCs were stamps corresponding to school items to be donated to a public school (placed on a counter in full view of the participants). VCCs were messages of approval or disapproval projected on the screen of a 42" LCD monitor. The monitor also displayed the 10 x 10 matrix shown in Figure 1. An additional laptop computer equipped with Microsoft PowerPoint 2013 ${ }^{\circledR}$ displayed these images.

\section{Environment}

The experimental sessions occurred in a $3 \mathrm{~m} \times 2.4 \mathrm{~m}$ room, with relative acoustic insulation and air conditioning. Participants and researchers stayed in a furnished room with a conference table and five chairs.

\section{Procedure}

General task. The participants attended one session per microculture. The projected matrix (Figure 1) contained 10 rows numbered 1 to 10 and 10 columns labeled A to J. The colors yellow, blue, green, red, and pink filled the rows of the matrix, with an even row and an odd row for each color. There was a filled circle or an empty circle in each intersection cell of the row with the column.

Three participants simultaneously performed the task. Each task cycle consisted of the following sequence of events: a) the experimenter requested a participant to announce his/her choice of row (the order of the participants on each cycle was randomly selected); b) the participant announced his/ her choice of row; c) the experimenter selected a column, through a semi-random system; d) if there was an empty circle in the cell intersecting the participant's and the experimenter's choices, one token (with a value of $\mathrm{R} \$ 0.05$ [the " $\mathrm{R} \$$ " is a standard symbol for the Brazilian currency]) was deposited in the container corresponding to the participant; if there was a filled circle, then three tokens ( $\mathrm{R} \$ 0.15$ ) were deposited; e) steps A through D were repeated for 


\section{EFFECTS OF VERBAL AND NONVERBAL CULTURAL CONSEQUENCES}

the other two microculture participants; and f) when applicable, according to the experimental condition in place, a stamp mark was posted on a card placed on the table signaling the production of a school item (NVCC) by the team of participants, and/or a message of approval or disapproval (VCCs) to the team was displayed on the LCD monitor.

Experimental design. Six experimental conditions were planned for each of the four microcultures: for M1 (competition) and M2 (no competition), we programmed an ABABCD design; for M3 (competition) and M4 (no competition), we scheduled a BABACD format.

In all conditions, there were operant contingencies and metacontingencies, except for the Condition $\mathrm{D}$, in which only operant contingencies were in place. The operant contingencies were the same across all conditions: one token (R\$ 0.05) was contingent upon choosing an even row (production of an IC of the smallest magnitude available); three tokens (R\$ 0.15) were contingent upon choosing an odd row (production of an IC of the greatest magnitude available).

\section{Table 1.}

Distribution of the participants into $M 1, M 2, M 3$, and M4 lineages

\begin{tabular}{|c|c|c|}
\hline MICROCULTURE & LINEAGE & PARTICIPANTS \\
\hline \multirow{3}{*}{ M1 (competition) } & M1L1 & $\begin{array}{l}\text { P1, P4, P7, P10, P13, P16, P19, P22, P25, P28, } \\
\text { P31. }\end{array}$ \\
\hline & M1L2 & $\begin{array}{l}\text { P2, P5, P8, P11, P14, P17, P20, P23, P26, P29, } \\
\text { P32. }\end{array}$ \\
\hline & M1L3 & $\mathrm{P} 3, \mathrm{P} 6, \mathrm{P} 9, \mathrm{P} 12, \mathrm{P} 15, \mathrm{P} 18, \mathrm{P} 21, \mathrm{P} 24, \mathrm{P} 27, \mathrm{P} 30$. \\
\hline \multirow{3}{*}{ M2 (no competition) } & M2L1 & $\begin{array}{l}\text { P33, P36, P39, P42, P45, P48, P51, P54, P57, } \\
\text { P60, P63. }\end{array}$ \\
\hline & M2L2 & $\begin{array}{l}\text { P34, P37, P40, P43, P46, P49, P52, P55, P58, } \\
\text { P61, P64. }\end{array}$ \\
\hline & M2L3 & $\begin{array}{l}\text { P35, P38, P41, P44, P47, P50, P53, P56, P59, } \\
\text { P62, P65. }\end{array}$ \\
\hline \multirow{3}{*}{ M3 (competition) } & M3L1 & $\begin{array}{l}\text { P66, P69, P72, P75, P78, P81, P85, P88, P91, } \\
\text { P94. }\end{array}$ \\
\hline & M3L2 & $\begin{array}{l}\text { P67, P70, P73, P76, P79, P82, P84, P86, P89, } \\
\text { P92. }\end{array}$ \\
\hline & M3L3 & P68, P71, P74, P77, P80, P83, P87, P90, P93. \\
\hline \multirow{3}{*}{ M4 (no competition) } & M4L1 & $\begin{array}{l}\text { P95, P98, P101, P104, P107, P110, P113, } \\
\text { P116, P119, P122. }\end{array}$ \\
\hline & M4L2 & $\begin{array}{l}\text { P96, P99, P102, P105, P108, P111, P114, } \\
\text { P117, P120, P123. }\end{array}$ \\
\hline & M4L3 & $\begin{array}{l}\text { P97, P100, P103, P106, P109, P112, P115, } \\
\text { P118, P121. }\end{array}$ \\
\hline
\end{tabular}

Note. $\mathrm{M} 1=$ Microculture 1; M1L1 = Microculture 1 and Lineage 1; P1 = Participant 1. The meanings of the letters apply for the other abbreviations with the same type of alphanumeric composition. 


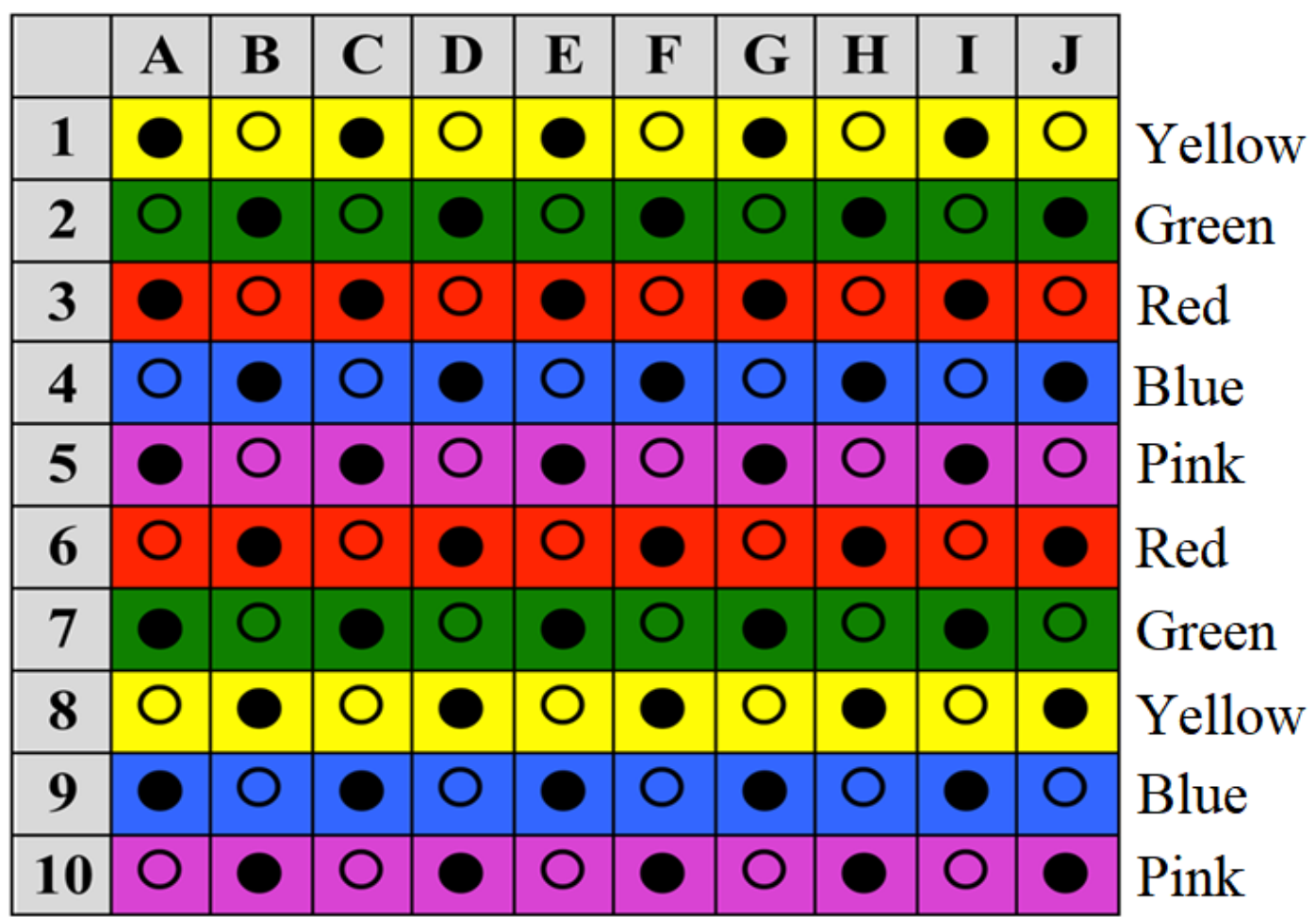

Figure 1.10 10 matrix indicating the colors of the rows

Metacontingencies varied according to the microcultures. For M1 and M3, competition between operant contingencies and metacontingencies were programmed; the target culturants were the choice of three even rows (smallest IC magnitudes) of different colors in one cycle; in M2 and M4, no competition was programmed; thus, the target culturants consisted only of the choice of three rows of different colors (which could be even or odd) on one cycle.

Under Condition A the nonverbal cultural consequence (NVCC) corresponded to an item to be donated to a school and was contingent upon the production of the expected culturant. A verbal cultural consequence (VCC) of approval was also contingent on the production of the culturant. The consequence was a note displayed on the LCD monitor written in green ("Congratulations! :) You did well this time!"); when the target culturant did not occur, we displayed a note written in red ("That was not good! : : You did not do well this time!"), corresponding to a VCC of disapproval. Under Condition B, the application of NCVVs was only for target culturants. Under Condition C, only VCCs of approval and disapproval were contingent on the occurrence or nonoccurrence of the target culturants. Under Condition D, both NVCCs and VCCs were suspended.

Table 2 shows the experimental conditions and the programmed operant contingencies and metacontingencies for the four microcultures. The criterion for termination of Conditions A, B, and $\mathrm{C}$ was the occurrence of $80 \%$ target culturants (Criterion 1) for 60 successive cycles in the same condition or the completion of 100 cycles (Criterion 2) if it did not reach Criterion 1. Condition D lasted 100 fixed cycles.

Participant replacement and generational changes. Each microculture had three participants simultaneously exposed to the experimental conditions, characterizing a generation. Replacements (generational changes) occurred every 20 cycles, when the participant who had been 


\section{EFFECTS OF VERBAL AND NONVERBAL CULTURAL CONSEQUENCES}

in session for the longest (60 cycles) was replaced, with the exception of the first and second generational substitution of each microculture, which occurred at the 20th and 40th cycles, respectively.

Instructions. Written instructions with a general description of the task, omitting the production criteria of ICs, VCCs, and NVCCs were provided to the first three participants of each microculture (P1, P2, and P3 of M1; P33, P34, and P35 of M2; P66, P67, and P68 of M3; and P95, P96, and P97 of M4), as follows (the bold words were present in the written instructions provided

Table 2.

Experimental design-M1 and M2 (ABABCD); M3 and M4 (BABACD)

\begin{tabular}{|c|c|c|c|c|c|}
\hline \multirow{2}{*}{ Microculture } & \multirow{2}{*}{ Condition } & \multicolumn{2}{|c|}{$\begin{array}{c}\text { Operant } \\
\text { contingencies }\end{array}$} & \multicolumn{2}{|c|}{ Metacontingencies } \\
\hline & & $\mathbf{R}$ & IC & Culturant & $\mathbf{C C}$ \\
\hline \multirow{6}{*}{$\begin{array}{c}\text { M1 } \\
\text { (competition) } / \\
\text { M2 } \\
\text { (no competition) }\end{array}$} & $\begin{array}{c}\mathrm{A} \\
(\mathrm{NVCCs}+\mathrm{VCCs})\end{array}$ & \multirow{3}{*}{$\begin{array}{l}\text { Even } \\
\text { Row }\end{array}$} & \multirow{3}{*}{$\begin{array}{c}1 \\
\text { token } \\
(\mathrm{R} \$ \\
0.05)\end{array}$} & \multirow{5}{*}{$\begin{array}{l}\text { Even rows of } \\
\text { different colors } \\
\text { (M1)/ Rows } \\
\text { with different } \\
\text { colors (M2) }\end{array}$} & $\begin{array}{c}1 \text { school } \\
\text { item }+ \\
\text { Approval }\end{array}$ \\
\hline & $\begin{array}{c}\mathrm{B} \\
(\mathrm{NVCCs}) \\
\end{array}$ & & & & $\begin{array}{l}1 \text { school } \\
\text { item }\end{array}$ \\
\hline & $\begin{array}{c}\mathrm{A} \\
(\mathrm{NVCCs}+\mathrm{VCCs})\end{array}$ & & & & $\begin{array}{c}1 \text { school } \\
\text { item }+ \\
\text { Approval }\end{array}$ \\
\hline & $\begin{array}{c}\mathrm{B} \\
(\mathrm{NVCCs}) \\
\end{array}$ & \multirow{3}{*}{$\begin{array}{l}\text { Odd } \\
\text { Row }\end{array}$} & \multirow{3}{*}{$\begin{array}{c}3 \\
\text { tokens } \\
(\mathrm{R} \$ \\
0.15)\end{array}$} & & $\begin{array}{l}1 \text { school } \\
\text { item }\end{array}$ \\
\hline & $\begin{array}{c}\mathrm{C} \\
(\mathrm{VCCs})\end{array}$ & & & & Approval \\
\hline & $\begin{array}{c}\mathrm{D} \\
(\mathrm{No} C \mathrm{Cs})\end{array}$ & & & $\begin{array}{c}\text { Any sequence } \\
\text { of rows }\end{array}$ & - \\
\hline \multirow{6}{*}{$\begin{array}{c}\text { M3 } \\
\text { (competition) / } \\
\text { M4 } \\
\text { (no competition) }\end{array}$} & $\begin{array}{c}\mathrm{B} \\
(\mathrm{NVCCs}) \\
\end{array}$ & \multirow{6}{*}{$\begin{array}{l}\text { Even } \\
\text { Row }\end{array}$} & \multirow{3}{*}{$\begin{array}{c}1 \\
\text { token } \\
(\mathrm{R} \$ \\
0.05)\end{array}$} & \multirow{5}{*}{$\begin{array}{c}\text { Even rows of } \\
\text { different colors } \\
\text { (M3) / Rows } \\
\text { with different } \\
\text { colors (M4) }\end{array}$} & $\begin{array}{l}1 \text { school } \\
\text { item }\end{array}$ \\
\hline & $\begin{array}{c}\mathrm{A} \\
(\mathrm{NVCCs}+\mathrm{VCCs})\end{array}$ & & & & $\begin{array}{c}1 \text { school } \\
\text { item }+ \\
\text { Approval }\end{array}$ \\
\hline & $\begin{array}{c}\mathrm{B} \\
(\mathrm{NVCCs}) \\
\end{array}$ & & & & $\begin{array}{l}1 \text { school } \\
\text { item }\end{array}$ \\
\hline & $\begin{array}{c}\mathrm{A} \\
(\mathrm{NVCCs}+\mathrm{VCCs})\end{array}$ & & \multirow{3}{*}{$\begin{array}{c}3 \\
\text { tokens } \\
(\mathrm{R} \$ \\
0.15)\end{array}$} & & $\begin{array}{c}1 \text { school } \\
\text { item }+ \\
\text { Approval }\end{array}$ \\
\hline & $\begin{array}{c}\mathrm{C} \\
(\mathrm{VCCs})\end{array}$ & & & & Approval \\
\hline & $\begin{array}{c}\mathrm{D} \\
(\mathrm{No} \mathrm{CCs})\end{array}$ & & & $\begin{array}{l}\text { Any sequence } \\
\text { of rows }\end{array}$ & - \\
\hline
\end{tabular}

Note. NVCCs $=$ Non-verbal cultural consequences; VCCs = Verbal cultural consequences; No CCs = No cultural consequences; $\mathrm{R}=$ Response; $\mathrm{IC}=$ Individual consequence; $\mathrm{CC}=$ Cultural consequence. 
to participants):

\begin{abstract}
You will participate in an activity in which, at each round, you must choose a row in a matrix with 10 rows (numbered 1 to 10) and 10 columns (labeled A to J). The matrix has yellow, green, red, blue, and pink rows. Right after your choice, the experimenter will select a column. If there is a filled circle at the intersection of the chosen row and the column you will receive three tokens. If the intersection cell contains an empty circle, then you will receive one token. Each token is exchangeable for R $\$ 0.05$ at the end of your participation. After you and the other participants have chosen your rows, one round (cycle) will have occurred. At the end of the round, the experimenter may make a stamp mark, which indicates the production of one school item of a kit of school supplies to be donated to a public school, with an average value of $\mathbf{R} \mathbf{\$} \mathbf{1 . 0 0}$ per item. After a few rounds, a new participant will replace the participant who has been in the activity for the longest time. Veteran participants should instruct new participants on the activity. You can interact freely with the other participants, according to your interests. If there are any questions, then ask now. The researcher will not be answering questions during the activity. A date will be set for the donation of the school supplies to the school. Those interested may participate in the delivery.
\end{abstract}

When a generational change occurred, the researcher presented the newcomer to the other members and provided the following information orally: "Instructions about the task will be given by the other participants. You can talk freely about the activity."

\title{
Results
}

The four microcultures (M1, M2, M3, and M4) were exposed to all of the specified conditions (Figures 2 and 3). M1 (competition) totaled 600 cycles, with all of the conditions ending based on Criterion 2. M2 (no competition) had a total of 511 cycles, with three conditions ending based on Criterion 1 (Conditions A, B [second exposure], and C) and the other two based on Criterion 2. M3 (competition) completed 600 cycles, with each condition ending based on Criterion 2. Finally, M4 totaled 532 cycles, with two conditions ending based on Criterion 1 (Conditions B [second exposure] and A [second exposure]) and the others based on Criterion 2. The duration of each microculture was 8 hours, on average.

Figure 2 shows the results for M1 (competition) and M2 (no competition) exposed to the ABABCD design. Overall, there was more variability in the occurrence rate of target culturants (red row) and in the production of individual consequences (ICs) in M1 (competition). In M1 (upper plot), the occurrence of target culturants started in cycle 37, but it remained unsystematic until the end of the condition. The transition to Condition B occurred with a rate of $37 \%$ target culturants in 60 cycles. In Condition B, in which there was the removal of VCCs of approval and disapproval and the maintenance of NVCCs, the occurrence rate of target culturants decreased to $13 \%$ at the transition to the following condition. With the reintroduction of VCCs in the second exposure to Condition A there was an increase in the rate of target culturants to $72 \%$ (cycle 256), and the rate was maintained between $50 \%$ and $60 \%$ until the end of the condition. Upon the removal of VCCs in Condition B (second exposure), there was an initial increase in the occurrence rate of the target culturants, followed by a reduction until the end of the condition, with a transition to the next condition at a rate of $58 \%$. There was a continued reduction of the occurrence of the 
\begin{tabular}{c|ccccc}
$\mathrm{A}$ & $\mathrm{B}$ & $\mathrm{A}$ & $\mathrm{B}$ & $\mathrm{C}$ & $\mathrm{C}$ \\
(NVCCs+VCCs) & (NVCCs) & (NVCCs+VCCs) & (NVCCs) & (VCCs) & (No CCs)
\end{tabular}

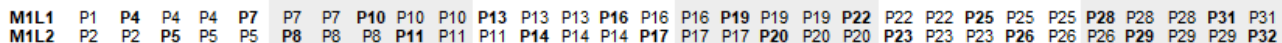

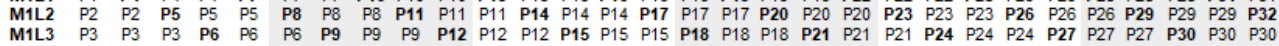
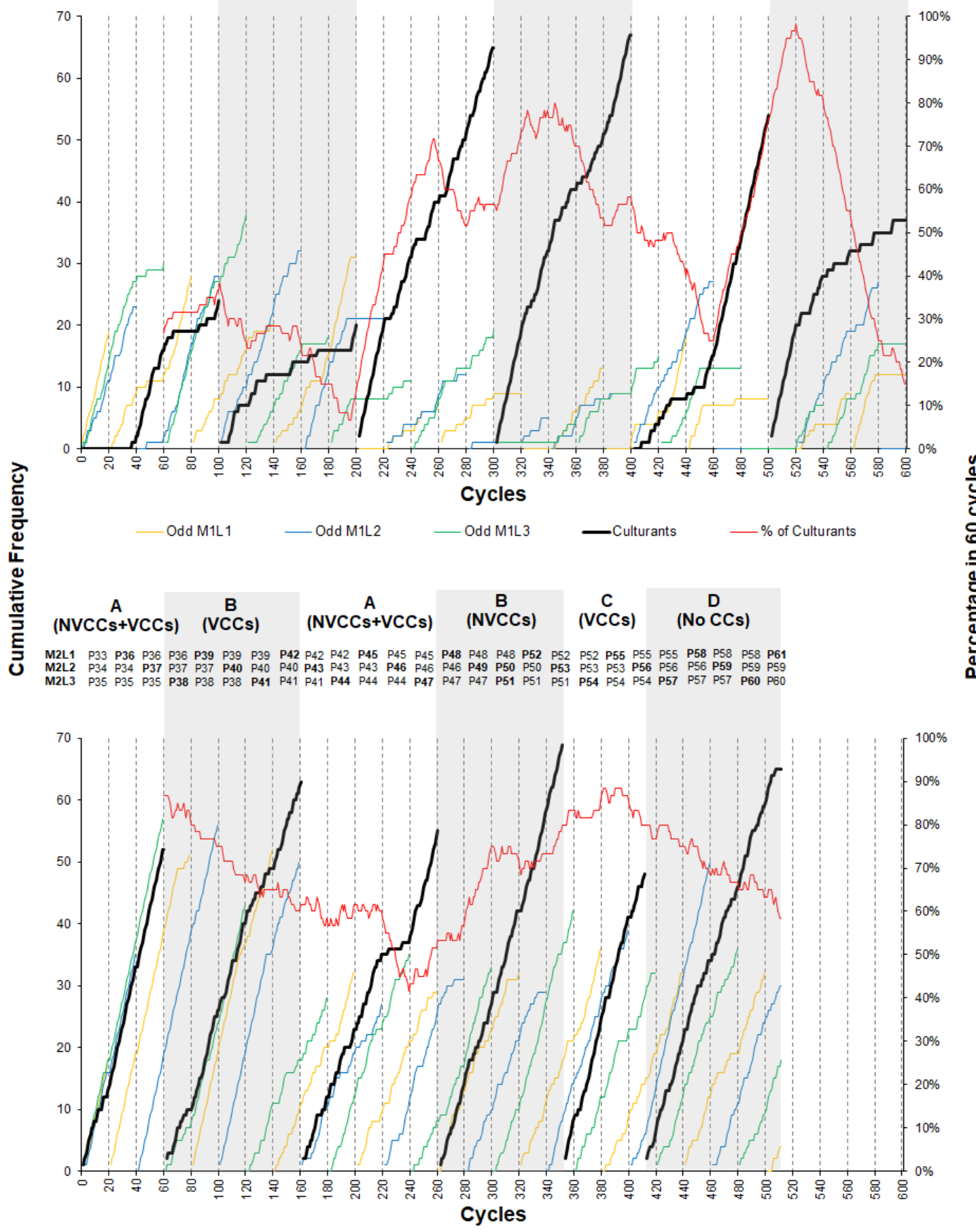

Odd M2L1

Odd M2L2

- Odd M2L3

- Culturants

$\%$ of Culturants

$<$ Caption follows $>$ 
Figure 2. Cumulative occurrence of responses on odd rows and occurrence of target culturants (left axis). Percentage of target culturants on the last 60 cycles (right axis). Horizontal axis marks cycles. Dashed vertical lines represent replacements of participants and generations. Upper plot represents M1; bottom plot M2.

target culturants in Condition $\mathrm{C}$, in which there was the removal of NVCCs and only VCCs remained. At the entry of $\mathrm{P} 26$, when a generation (P24, P25, and P26) that had not come into contact with the participants from the previous condition was formed, target culturants occurred more systematically, and the final condition was reached with a rate of $77 \%$ of culturant production. In Condition D, in which NVCCs and VCCs were suspended, the increasing rate of culturant production maintained until the entry of P29: from this point on there was a gradual reduction in the occurrence of target culturants, with the experiment ending at a rate of $15 \%$ for microculture M1. M2 (no competition) was exposed to the same order of experimental conditions as M1 (competition) but there was no competition between operant contingencies and metacontingencies (Figure 2, bottom plot). The occurrence of target culturants began in the first cycle of Condition A and was maintained until the end of the condition. At the transition to the following condition, the rate of target culturants at 60 successive cycles was $87 \%$. After the removal of VCCs in Condition B, there was a gradual reduction in the occurrence of target culturants, transitioning to the next condition with a rate of $62 \%$. With the re-reintroduction of VCCs in Condition A (second exposure), the rate of target culturants remained stable for a few cycles fluctuating until the conclusion of the condition, with the transition to the following condition at 53\% with an increasing trend. The increasing trend in the occurrence of target culturants was maintained with the removal of VCCs in Condition B (second exposure), and the transition to the following condition occurred with an $80 \%$ ratio (Criterion 1). In Condition $\mathrm{C}$, in which only VCCs were present, the rate of target culturants remained between $80 \%$ and $90 \%$ for 60 cycles. Exposure to the suspension of VCCs and NVCCs resulted in a gradual reduction in the occurrence of target culturants, with the experiment ending at a rate of $58 \%$.

Figure 3 shows the results for M3 (competition) and M4 (no competition) exposed to the BABACD design. The difference in the variability of the occurrence of target culturants between M3 (competition) and M4 (no competition) was greater than that observed between M1 and M2. In M3 (upper plot), there was a prevalence of individual responses in the odd rows in Conditions B, A, and B (second exposure). The occurrence of target culturants started only at cycle 304, at the second exposure to Condition A, when VCCs were re-introduced. In this condition, the recurrence of target culturants reached a maximum rate of 55\% at 60 successive cycles, a percentage that decreased to $40 \%$ at the transition to the following condition. When only VCCs were present, in Condition $\mathrm{C}$, the rate of target culturants gradually decreased to $10 \%$ at the end of the condition. With the removal of all cultural consequences (CCs), the occurrence rate of target culturants did not exceed $20 \%$.

In M4 (Figure 3, bottom plot), VCCs and NVCCs had a greater effect on target culturants in the condition of no competition between metacontingências and the operant contingency. Already in the first cycle of Condition B, the target culturant occurred, and there was a gradual increase in the occurrence rate of target culturants until the transition to the following condition, with $63 \%$ of 60 cycles with culturant production. The introduction of VCCs in Condition A, resulted in the occurrence rate of target culturants that maintained between $60 \%$ and $70 \%$ throughout the condition. When Condition B, which had only NVCCs, was reinstated there was an increase in the occurrence rate of target culturants, and Criterion 1 was reached at cycle 275 . With the reintroduction of VCCs in the second exposure to Condition A, a rate of $86 \%$ of target culturants 

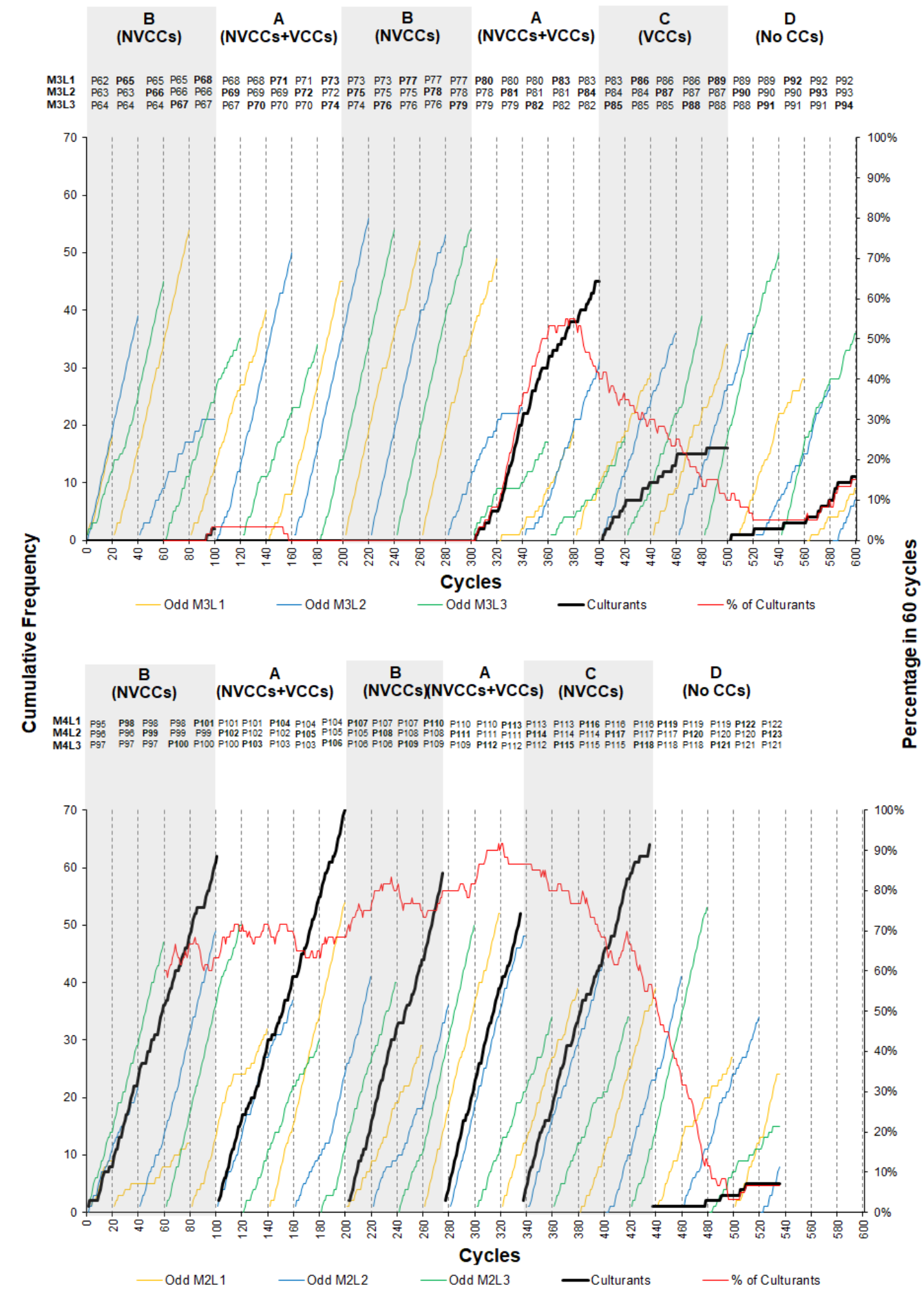

\section{$<$ Caption follows $>$}


Figure 3. Cumulative occurrence of responses on odd rows and occurrence of target culturants (left axis). Percentage of target culturants on the last 60 cycles (right axis). Horizontal axis marks cycles. Dashed vertical lines represent replacements of participants and generations. Upper plot represents M3; bottom plot M4.

reached the Criterion 1. In Condition $\mathrm{C}$, when there was the removal of NVCCs and only VCCs remained in effect, the rate of target culturants deteriorated until the end of the condition, and the transition to the final condition occurred at a value of $56 \%$. In Condition D, in which VCCs and NVCCs were suspended, performance degradation was maintained, and the experiment ended with a recurrence rate of target culturants of $6 \%$.

\section{Discussion}

The aim of this study was to examine the effects of NVCCs and VCCs of approval and disapproval on culturants under conditions of competition and no competition between metacontingencies and operant contingencies. Reaching Criterion 1 was one important indicator of selection of target culturants, but occurred only in the microcultures in which this competition was not present (M2 and M4). For microcultures M1 and, in particular, M3, the evidence of selection of target culturants by CCs was less conclusive, although there were some effects that must be discussed.

Previous exposure to the experimental task may have influenced the occurrence of target culturants in the second exposure to an experimental condition for all microcultures. Previous studies with the same protocol reported this effect (e.g., Borba et al., 2017; Hosoya \& Tourinho, 2016; Soares et al., 2012). Although Criterion 1 was never reached in M1, there is evidence of selection of target culturants by NVCCs + VCCs in the second exposure to Condition A, a performance that is maintained in the next condition (B, second exposure), even with the removal of VCCs. This result suggests that the association of VCCs and NVCCs may be an important element for the selection of target culturants in a context of competition between operant contingencies and metacontingencies and that once selected, performance may be maintained with the presence of NVCCs only.

During the second exposures to Condition A for M1, there is a reduction in the percentage of occurrence of target culturants: from around $70 \%$ on cycle 260 to $52 \%$ on the following cycles. There is another significant reduction of target culturants after cycle 360 during the second exposition to Condition B. In both cases there are indicators of performance recovery by the end of each condition. These variations in performance suggest that the substitution of participants and the presence of newcomers who were not exposed to the immediately preceding conditions are a relevant variable. In Condition $\mathrm{C}$, a more evident change in the rate of target culturants occurred after cycle 450 when all participants composing a generation had not been exposed to the previous condition; however, instead of a reduction in the percentage of target culturants, as in Conditions A (second exposure) and B (second exposure), there was a steady increase in the production of target culturants, suggesting that VCCs may have a strong effect on the selection of culturants if there is not an experimental history with NVCCs (Azevedo \& Todorov, 2016; Martins \& Tourinho, 2014; Soares \& Tourinho, 2014; Vasconcelos \& Todorov, 2015).

There was competition in microcultures M3 and M1, but the order of presentation of the conditions was alternated (BABACD for $\mathrm{M} 3$, ABABCD for M1). The higher frequency of occurrence of target culturants in M1, when compared to M3, strengthens the conclusion about the selective role of cultural consequences that encompass both VCCs and NVCCs. M3 was first 
exposed to a condition without VCCs (B), which generated a prevalence of responses that generated more tokens. The frequency of target culturants changed significantly only after the second introduction of Condition A, confirming the suggestion of Gomes and Tourinho (2016) with regard to the importance of VCCs in a context of competition between operant contingencies and metacontingencies. In Condition $\mathrm{C}$, the performance of M3 was not maintained, which is different from what was observed with M1. For M3, the application of VCCs happened after a history of association with NVCCs, which seems to have affected the possibility of a selective effect of messages of approval and disapproval (VCCs) presented without the production of school items (NVCCs).

Microculture M2 replicated the sequence of conditions of M1 but there was no competition between operant contingencies and metacontingencies. There was less variation in the production of target culturants and Criterion 1 for change in experimental conditions was obtained during the second exposures to Conditions A and B and in Condition C. Results for M3 and M4 also reveal that competition between operant contingencies and metacontingencies interfere with the selection and maintenance of selected culturants: For M3 selection only occurred on the second exposition of Condition A and was almost immediately disrupted by the introduction of Condition $\mathrm{C}$, whereas for M4 the production of target culturants was maintained above the $60 \%$ level in all conditions and was disrupted only when cultural consequences were suspended (Condition D). These results emphasize the important role of the competition context pertaining the selection and maintenance of culturants, as already observed in some studies (e.g., Borba et al., 2017; Magalhães, 2013).

Microcultures M2 and M4 showed high and, for the most part, stable levels of target culturant occurrence. The successive changes in cultural consequences had a lesser effect in these cases than they did with M1 and M3. For M1 and M2, the production of culturants maintained when Condition C-VCCs replaced NVCCs - followed Condition B. Thus, VCCs had a maintenance effect when disassociated from NVCCs. The same may be said for M4: the production of culturants was high during Condition $\mathrm{C}$ (following the second exposure to Condition A). But VCCs alone were not sufficient to maintain the production of culturants for M3 suggesting a competitive context in which both consequences - NVCC and VCC - are necessary to promote selection and maintenance of metacontingencies.

In all of the microcultures, the suspension of VCCs and NVCCs (Condition D) resulted in a reduction in the production of target culturants. In M2, the performance in the previous condition probably aided in the evidence of "resistance to extinction", when Criterion 1 was met, and to the absence of competition (Borba et al., 2017; Caldas, 2009; Costa et al., 2012; Ortu et al., 2012; Vichi, 2012).

The results of this study can be summarized as follows: 1) competition between operant contingencies and metacontingencies interfered with selection of target culturants by VCCs and NVCCs; 2) VCCs and NVCCs had a selective and maintenance role when combined, with or without competition between operant contingencies and metacontingencies, but some factors such as previous experience, experimental history and individual performances predominantly incompatible with the production of target culturants in previous conditions limited their selective effects; 3) VCCs had a selective and maintenance effect when in effect after a condition in which they were not associated with NVCCs, in contexts with or without competition; 4) NVCCs selected target culturants when there was no competition, but did not select them in a competitive situation; 5) NVCCs alone maintained target culturants, with or without competition; and 6) the suspension of NVCCs and VCCs tended to generate a fast deterioration of culturant production which was strongly affected by competition between operant contingencies and metacontingencies. 
In the beginning of the present report, we mentioned "Programa Bolsa Familia", a social program funded by the Government of Brazil. Our results support the perspective presented by Fava and Vasconcelos (2017). The selection of relevant culturants (e.g., school attendance by children) may fail when relying only on the benefit money (NVCCs) as the cultural consequence. Competing operant contingencies may overcome the requested coordination of behaviors. However, when government officials clarify the program regulations (VCCs) to the benefited, such intervention may function as additional cultural consequences. The combination of NVCCs (cash benefit) and VCCs (e.g., emphasis on consequences of noncompliance with regulations) may improve the selective effects upon the target culturants.

In the experiment, the direct manipulation of VCCs, associated with and disassociated from NVCCs, showed that these consequences have differential effects on the production of culturants. The presentation of verbal messages such as "Congratulations!" or "Not this time!" had a selective effect on target culturants and must be taken into account in experiments with metacontingencies. There are differences in the effect on the recurrence rates of target culturants if a message of approval/disapproval is presented or if no verbal feedback is offered.

Although there was observation of the selective effects of VCCs and NVCCs on target culturants, the evaluation of the role of this variable requires closer examination. The exposure of microcultures to conditions of isolated and alternated presentation of VCCs and NVCCs can provide important information. Verbal consequences of approval and disapproval, applied individually, should also have their effects examined. Removing generational changes and providing more details on the characteristics of the experimental task (thus facilitating information sharing between veteran and newcomer participants) could minimize the effects generated by the exposure time to the activity.

\section{References}

Andery, M. A. P. A., Micheletto, N., \& Sério, T. M. A. P. (2005). A análise de fenômenos sociais: Esboçando uma proposta para a identificação de contingências entrelaçadas e metacontingências. [An analysis of social phenomena: Outlining a proposal for identification of interlocking contingencies and metacontingencies]. Revista Brasileira de Análise do Comportamento, 1, 149-165. doi:10.18542/rebac.v1i2.2167.

Azevedo, R. M. F., \& Todorov, J. C. (2016). Controle de estímulos e contraste comportamental em uma tarefa de cooperação. [Stimuli control and behavioral contrast in a cooperation task]. Revista Brasileira de Análise do Comportamento, 12(2), 95-105. doi:10.18542/rebac.v12i2.4402.

Baia, F. H., Lemes, I. G., Biano, A. B. C., Pereira, R. S. C., \& Sousa, L. D. (2017). Efeitos da programação e suspensão de metacontingências sobre operantes e culturantes. [Effects of establishment and withdrawal metacontingencies upon operants and culturants]. Acta Comportamentalia, 25(4), 495-510.

Baia, F. H., \& Vasconcelos, L. A. (2015). Efeitos de consequências culturais concorrentes na seleção de culturantes. [Effects of concurrent cultural consequences on the selection of culturants]. Revista Brasileira de Análise do Comportamento, 11(2), 125-134. doi:10.18542/rebac.v11i2.3781.

Borba, A., Tourinho, E. Z., \& Glenn, S. S. (2017). Effects of cultural consequences on interlocking behavior contingencies of ethical self-control. Psychological Record, 67(3), 399-411. doi:10.1007/s40732-017-0231-6.

Caldas, R. A. (2009). Análogos experimentais de seleção e extinção de metacontingências. [Experimental analogs of selection and extinction of metacontingencies] (Master's Thesis, Pontifícia Universidade Católica de São Paulo, São Paulo, Brazil).

Carvalho, L. C. (2016). Metacontingency in pairs of fish (Melanotaenia boesemani): A proposed setup to investigate cultural selection. Journal of Behavior, Health \& Social Issues, 8(1), 35-39. doi:10.1016/j.jbhsi.2017.08.004.

Carvalho, L. C., Couto, K. C., Gois, N. S., Sandaker, I., \& Todorov, J. C. (2017). Evaluating effects of cultural consequences on the variability of interlocking behavioral contingencies and their aggregate products. European Journal of Behavior Analysis, 18(1), 84-98. doi:10.1080/15021149.2016.1231003.

Costa, D., Nogueira, C., \& Vasconcelos, L. (2012). Effects of communication and cultural consequences on choices combinations in INPDG with four participants. Revista Latinoamericana de Psicologia, 44(1), 121-131. 


\section{EFFECTS OF VERBAL AND NONVERBAL CULTURAL CONSEQUENCES}

Fava, V. M. D., \& Vasconcelos, L. A. (2017). Behavior of Programa Bolsa Família beneficiaries: A behavior analytic perspective on fulfillment of education and health conditionalities. Behavior and Social Issues, 26, 156-171. doi:10.5210/bsi.v.26i0.782.

Gerard, R. W., Kluckhohn, C., \& Rapoport, A. (1956). Biological and cultural evolution: Some analogies and explorations. Behavioral Science, 1(1), 6-34. doi:10.1002/bs.3830010103.

Glenn, S. S. (2003). Operant contingencies and the origin of cultures. In K. A. Lattal \& P. N. Chase (Eds.), Behavior theory and philosophy (pp. 223-242). New York: Kluver/Plenum.

Glenn, S. S. (2004). Individual behavior, culture, and social change. The Behavior Analyst, 27(2), 133-151. doi:10.1007/BF03393175.

Glenn, S. S., Malott, M. E., Andery, M. A. P. A., Benvenuti, M., Houmanfar, R. A., Sandaker, I., Todorov, J. C., Tourinho, E. Z., \& Vasconcelos, L. A. (2016). Toward consistent terminology in a behaviorist approach to cultural analysis. Behavior and Social Issues, 25, 11-27. doi:10.5210/bsi.v.25i0.6634.

Gomes, H. C. R., \& Tourinho, E. Z. (2016). Metacontingências de autocontrole ético: Efeitos do aumento da magnitude de reforço. [Metacontingencies of ethical self-control: Effects of increase in the reinforcement magnitude]. Psicologia: Teoria e Pesquisa, 4, 1-8.

Gonçalo, M. E. (2015) Efeitos da consequência cultural sobre a seleção de contingências comportamentais entrelaçadas em um contexto de descrição da metacontingência. [Effects of the cultural consequence on the selection of interlocking behavioral contingencies in a context of description of the metacontingency]. (Master's Thesis, Universidade Federal do Pará, Belém, Brasil).

Hosoya, N. M. S., \& Tourinho, E. Z. (2016). Efeitos de interações verbais na seleção e manutenção de contingências comportamentais entrelaçadas. [Effects of verbal interactions on the selection and maintenance on interlocking behavioral contingencies]. Acta Comportamentalia, 24(3), 331-345.

Jacobs, R. C., \& Campbell, D. T. (1961). The perpetuation of an arbitrary tradition through several generations of a laboratory microculture. Journal of Abnormal and Social Psychology, 62, 649-658. doi:10.1037/h0044182.

Magalhães, F. G. (2013). Efeitos da incompatibilidade entre consequências individuais e culturais em análogos experimentais de metacontingência. [Effects of incompatibility between individual and cultural consequences in experimental analogs of metacontingency]. (Doctoral Dissertation, Pontifícia Universidade Católica de São Paulo, SP, São Paulo).

Marques, N. S., \& Tourinho, E. Z. (2015). The selection of cultural units by non-contingent cultural events. Behavior and Social Issues, 24, 126-140. doi:10.5210/bsi.v.22i0.4283.

Martins, J. C. T., \& Tourinho, E. Z. (2014). Efeitos da suspensão da consequência cultural (CC) sobre a recorrência de contingências comportamentais entrelaçadas (CCEs) após a seleção de CCEs por CCs contínuas, em metacontingência concorrente com contingência operante. [Effects of suspension of cultural consequence (CC) on the recurrence of interlocking behavioral contingencies (IBCs) after selection of IBCs by continuous CCs, in metacontingency concurrent with operant contingency]. Report of Scientific Initiation, Universidade Federal do Pará, Núcleo de Teoria e Pesquisa do Comportamento [Behavior Theory and Research Unit], Belém, Brazil.

Oda, L. V. (2009). Investigação das interações verbais em um análogo experimental de metacontingência. [Investigation of verbal interactions in an experimental analog of metacontingency] (Master's Thesis, Pontifícia Universidade Católica de São Paulo, São Paulo, Brasil).

Ortu, D., Becker, A. M., Woelz, T. A. R., \& Glenn, S. S. (2012). An iterated four-player Prisoner's Dilemma Game with an external selecting agent: A metacontingency experiment. Revista Latinoamericana de Psicología, 44, 111-120.

Sampaio, A. A., Araújo, L. A. S., Gonçalo, M. E., Ferraz, J. C., Alves Filho, A. P., Brito, I. S., Barros, N. M., \& Calado, J. I. F. (2013). Exploring the role of verbal behavior in a new experimental test for the study of metacontingencies. Behavior and Social Issues, 22, 87-101. doi:10.5210/bsi.v22i0.4180.

Skinner, B. F. (1953). Science and human behavior. New York: MacMillan.

Smith, G. S., Houmanfar, R., \& Louis, S. J. (2011). The participatory role of verbal behavior in an elaborated account of metacontingency: From conceptualization to investigation. Behavior and Social Issues, 20, 122146. doi:10.5210/bsi.v20i0.3662.

Soares, P. F. R., \& Tourinho, E. Z. (2014). Efeitos da suspensão de consequências culturais (CCs) sobre práticas culturais previamente expostas a CCs intermitentes (VR3), em metacontingências concorrente e nãoconcorrente com contingência operante. [Effects of suspension of cultural consequences (CCs) on cultural practices previously exposed to intermittent CCs (VR3), in metacontingencies concurrent and non-concurrent 


\section{SOARES ET AL.}

with operant contingency). Report of Scientific Initiation, Universidade Federal do Pará, Núcleo de Teoria e Pesquisa do Comportamento [Behavior Theory and Research Unit], Belém, Brazil.

Soares, P. F. R., Cabral, P. A. A., Leite, F. L., \& Tourinho, E. Z. (2012). Efeitos de consequências culturais sobre a seleção e manutenção de duas práticas culturais alternadas. [Effects of cultural consequences on the selection and maintenance of two alternated cultural practices]. Revista Brasileira de Análise do Comportamento, 8(1), 37-46. doi:10.18542/rebac.v8i1.1826.

Tadaiesky, L. T., \& Tourinho, E. Z. (2012). Effects of support contingencies and cultural consequences on the selection of interlocking behavioral contingencies. Revista Latinoamericana de Psícologia, 44, 133-147.

Tourinho, E. Z., \& Vichi, C. (2012). Behavioral-analytic research of cultural selection and the complexity of cultural phenomena. Revista Latinoamericana de Psicologia, 44, 169-179.

Vasconcelos, I. G., \& Todorov, J. C. (2015). Experimental analysis of the behavior of persons in groups: Selection of an aggregate product in a metacontingency. Behavior and Social Issues, 24, 111-125. doi:10.5210/bsi.v24i0.5424.

Velasco, S. M., Benvenuti, M. F. L., Sampaio, A. A., \& Tomanari, G. Y. (2017). Cooperation and metacontingency in pigeons. The Psychological Record, 67(4), 537-545. doi:10.1007/s40732-017-0256-x.

Vichi, C. (2012). Efeitos da apresentação intermitente de consequências culturais sobre contingências comportamentais entrelaçadas e seus produtos agregados. [Effects of intermittent presentation of cultural consequences on interlocking behavioral contingencies and its aggregate products]. (Doctoral Dissertation, Universidade Federal do Pará, Brasil).

Weick, K. E., \& Gilfillan, D. P. (1971). Fate of arbitrary traditions in a laboratory microculture. Journal of Personality and Social Psychology, 17, 179-91. doi:10.1037/h0030461. 